\title{
A Model for Customer Loyalty in the healthcare centers Case Study Shahid Shooride medical center
}

\author{
Azade FATEMIFAR $^{1 *}$, Mirza Hassan Hosseini ${ }^{2}$, Mohammad Mahmoudi MAYMAND $^{3}$ \\ ${ }^{1}$ Master of Business Administration Payame Noor University Tehran \\ ${ }^{2}$ Associated professor of Department of Business Administration Payame Noor University, \\ Tehran, \\ ${ }^{3}$ Associated professor of Department of Business Administration \& MBA, \\ Payame Noor University, PO Box 19395-3697 Tehran, IRAN \\ *Corresponding author: Fatemifar@gmail.com
}

\begin{abstract}
Customer loyalty as a vital issue is considered for growth and survival of organizations in the competitive world. In this way, the cause and effect relationship between five latent variables were analyzed including social responsibility, trust, customer company identification, satisfaction, and patient loyalty and having 9 hypotheses.

To test the hypotheses the personal questionnaire was used and data from 405 individuals who referred to the Shahid Shoorideh medical Center was collected. randomly sampling method used and data was analyzed by statistical instruments. The descriptive statistics was performed using SPSS software and referential statistics was conducted using exploratory and confirmatory factor analysis and Structural Equation models and AMOS software. Result showed that the positive and significant relationship between corporate social responsibility, trust and customer company identification, and also relationship between patient's satisfaction, customer company identification and trust was supported. The relationship between corporate social responsibility and customer satisfaction, and also relationship between loyalty and customer satisfaction was rejected. Accordingly, the effect of social responsibility on loyalty was approved indirectly having considered the mediating role of customer trust, customer company identification, and patient satisfaction. In addition, result represents the important role of trust and customer company identification in patients' loyalty toward medical centers.
\end{abstract}

Keywords: organizational social responsibility, patient's trust, patient's satisfaction, customer company identification, loyalty. 


\section{Introduction}

Creation of customer loyalty is not only a marketing important goal, but also is an important foundation for the development of sustainable competitive advantage [1]. Customer loyalty is defined as a customer attitudes and behavior in relation to a specific service company, despite of the various services offered by competitors in the market [2]. The consequences of customer loyalty in service organizations, increase revenues, reduce customer acquisition costs and lower cost of repeat purchase services, which benefits more evenly [3]. Healthcare is also one type of the of the human-centered services provided and medical centers are prime in terms of importance between personal services. Long-term healthcare providers were resistant to use of official marketing activities in their performance [4]. There was no thinking about marketing in hospitals, nursing homes, clinics and rehabilitation centers until 1970. Even in recent years, professional centers do not like word fusion between healthcare and marketing and make misconstruction of many marketing promotions. Recently, however, the situation is changing with switching the focus of an organization oriented towards consumer-centric product or service. Marketer are indirectly targeting on serving customer to improve customer relationships and increase organization's revenue [4]. To enhance service delivery model, the connection between healthcare provider and patient needs has been developed. Also medical centers found that customer satisfaction is not enough to keep them in competition. They must also ensure that satisfied customers will be loyal [5]. The strategic importance of emotional concepts (such as customer company identification, trust and satisfaction) as fundamental variables As the underlying concepts in relationship marketing perspective, made studying it as a major step towards fulfilling their role in customer knowledge [6]. A number of studies have considered the effects of the corporate social responsibility on loyalty will be better explained by analyzing the role of social identity variables (customer company identification) and social exchange variables (trust and satisfaction) [7]. Since the relationship between organizations and their customers services are base on perceptions and other subjective and intangible factors, loyalty between service provider and customer is one of the distinctive characteristics in the service sector and activists in this part of the loyalty gain many benefits [8]. Due to the similarity of services which provided at healthcare centers, the competition is very fierce to attract customers and requires attention to factors that are induced differentiation and customer acquisition. In this study have been investigated the effect of corporate social responsibility on customer loyalty Taking into account mediating factors such as the customer company identity and trust and satisfaction The main purpose of this study is focused on corporate social responsibility as a marketing tool and study its impact on customer loyalty in medical Center and to develop a model for their loyalty. The main question is what model can be offered for customer loyalty in healthcare centers?

\section{Theoretical framework}

Over the last few decades new cultural values as a result of awareness of the interdependency among organizations Society and the environment, has been demonstrated. People have gradually realized which organizations' actions Gains and losses for community. Therefore a Plentiful attention have focused to improve impact of organization on community. In other words, society expects to receive, more than net profit from organizations [5]. As researches have shown, corporate Social responsibility is a potentially valuable area of strategic development, building positive view of the customer 
toward the service providers especially in health centers and has the potential to strengthen the image of healthcare centers in the community and lead to improve financial performance [9]. Customers basically are carrying a data search for healing work. Assessment processes of options result in chosen and Functional diagnostics of each hospital service [10]. Social responsibility has several definitions in healthcare field. A definition by Christian and Posner (2004) stated: Through responsible business conduct not only for the organization but also for stakeholders and community create value through their practices [4]. As part of the community hospital has a social responsibility Kotler and Lee (2005) suggested that corporate social responsibility is Commitment to improving the welfare of society through the practical implications of the specialized trade and the exploitation of resources. Hospital Institute is part of the environment. As part of social capital it has social responsibility. The social responsiveness role that is expected from commercial entity is sensitivity and concern for community respond to their social environment [10]. Customer company identification is refer to consumer's psychological attachment to company based on substantial overlap between their perception of themselves and of the company [11]. As Kotler (2009) argued customers use organizational identity to define themselves socially. Customer may also create cognitive conception of belonging and using organization to satisfy their self-definition. In general people tend to obtain positive sense of own so in search of a sense of identity with health centers which show the desirable features [12]. As Brown and Dacin (1997) suggested Participation in social responsibility with respect to the requirements of society affect their organization position and activities. Corporate social responsibility activities create an organizational identity and personality which allows stakeholders to identify with company on an assessment of overlap between their identity and organization's identity [7]. Aquino and Reed (2002) suggested that individuals are more likely to identify with those companies with higher levels of CSR in order to express a more ethical and social image and increase their self-esteem [11]. According to Corseby et al customer trust means the belief that can be relied on service provider to act in such a way that provide customer long-term benefits [7]. Mayer et al. considered three dimension of Benevolence, Integrity and Competence as trust dimensions [13]. Trust is an asset that healthcare centers can be used to create positive results in any communication or interaction with the patients [14]. To obtain loyalty must first gain their trust. Social exchange theories state that: This is very normal that ones exclusively deal with those who have shown themselves reliable [15]. Socially responsible behavior encourages, trust to the medical center. Ethical dimension has a major role in shaping this feeling. When patients feel that medical center treats ethical, trust transfer to the consumer [16]. Satisfaction is related to the extent to which patient expectations is fulfilled by medical services. Medical centers consider customer satisfaction as a basic strategy to gain customer loyalty, improve willing to pay and increase lifetime customer value for the organization [4]. Since the relationship between healthcare centers and their clients are on the basis of perceptions and other subjective and intangible factors, loyalty is one of the distinctive characteristics between service provider and customer in the service sector And activists gain many benefits in this part of the loyalty [8]. 


\section{Literature review}

Table 1: Findings from the literature review

\begin{tabular}{|l|l|}
\hline \multicolumn{1}{|c|}{ Summary and Conclusions literature } & Researcher \\
\hline $\begin{array}{l}\text { The impact of corporate social responsibility, customer company } \\
\text { identification on customer loyalty was investigated. The results showed that } \\
\text { leadership in social responsibility leads to stronger customer loyalty. }\end{array}$ & $\begin{array}{l}\text { Marin et al } \\
2009\end{array}$ \\
\hline $\begin{array}{l}\text { In this research were studied at a famous hospital in Kenya. Brand salience, } \\
\text { brand excellence, brand image, patient's trust and satisfaction variables } \\
\text { investigated and stated The hospital, should build confidence by satisfaction } \\
\text { that these two leads to patient loyalty. }\end{array}$ & $\begin{array}{l}\text { Jayakrishna } \\
\text { n } 2010\end{array}$ \\
\hline $\begin{array}{l}\text { Impact of corporate social responsibility, service quality, customer company } \\
\text { identification, customer satisfaction on loyalty was evaluated. Result showed } \\
\text { corporate social responsibility and service quality have direct influence on } \\
\text { identification and satisfaction. }\end{array}$ & $\begin{array}{l}\text { He and Lii } \\
2011\end{array}$ \\
\hline $\begin{array}{l}\text { People who had been visited in a ophthalmology clinic In South Africa were } \\
\text { studied. Results showed customer satisfaction has The highest correlation } \\
\text { with customer loyalty and there is positive relation between customer trust } \\
\text { and commitment and customer loyalty }\end{array}$ & $\begin{array}{l}\text { Van - } \\
2012\end{array}$ \\
\hline $\begin{array}{l}\text { Impact of corporate social responsibility service quality, customer company } \\
\text { identification, customer satisfaction on loyalty was evaluated. Result showed } \\
\text { That both social responsibility and service quality, had positive effect on the } \\
\text { customer related consequences like customer company identification, } \\
\text { customer satisfaction and loyalty. }\end{array}$ & $\begin{array}{l}\text { Arikan \& } \\
\text { 2013 }\end{array}$ \\
\hline $\begin{array}{l}\text { The role of factors like emotions, customer company identification and } \\
\text { customer satisfaction as mediating factor between social responsibilities and } \\
\text { were investigated. result showed social responsibilities had positive effect on } \\
\text { customer satisfaction and create loyalty }\end{array}$ & $\begin{array}{l}\text { Perez \& } \\
\text { Bosque } \\
2014\end{array}$ \\
\hline $\begin{array}{l}\text { In an investigation that was done in a hospital, showed social responsibilities } \\
\text { had effect on patient trust and loyalty }\end{array}$ & $\begin{array}{l}\text { Kumar et } \\
\text { al } 2014\end{array}$ \\
\hline
\end{tabular}

According to the literature, the researchers investigated impact of the four variables, the patients trust, patient satisfaction and customer company identification on loyalty to medical center. And finally delivered a model 


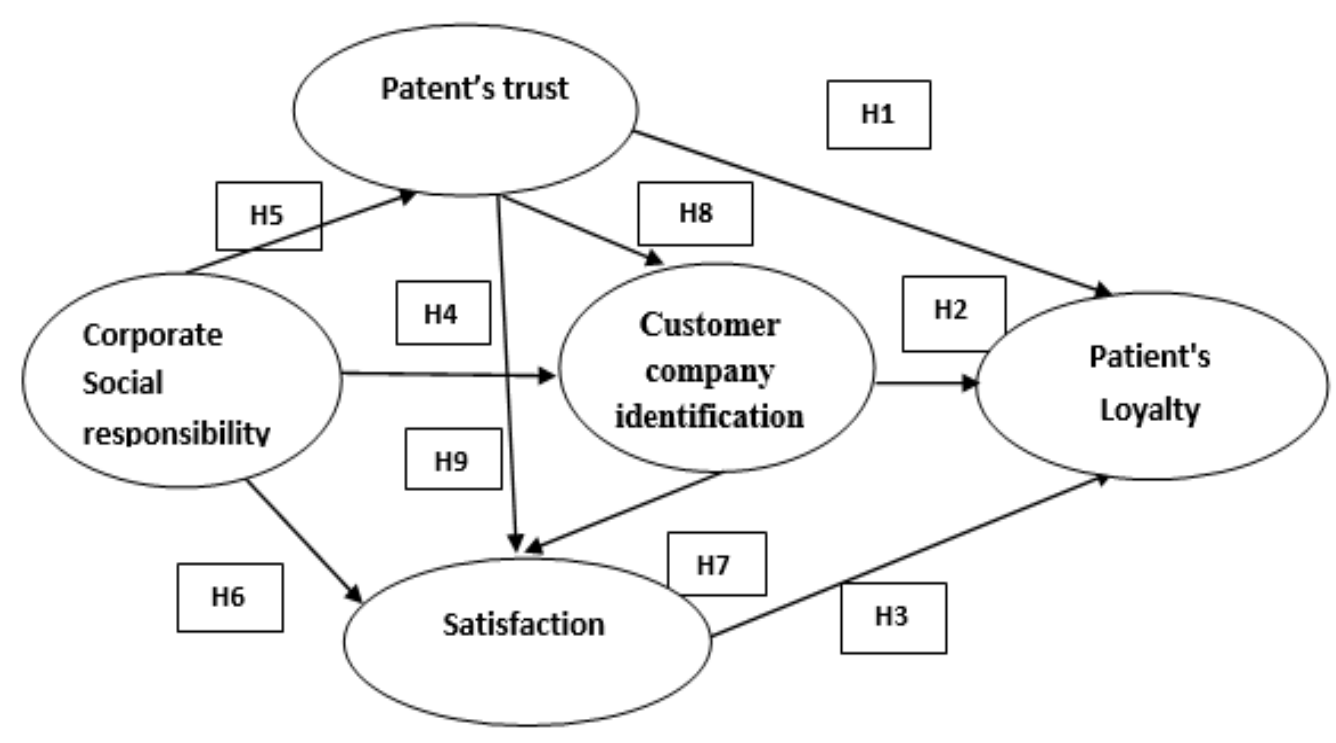

Figure 1: Conceptual model

\section{In this way, the hypothesis was formed in the following manner:}

H1: patient's trust has direct and meaningful relation with customer loyalty

$\mathrm{H} 2$ : Customer company identification has direct and meaningful relation with customer loyalty

H3: Customer satisfaction has direct and meaningful relation with patient's loyalty

H4: CSR has direct and meaningful relation with Customer company identification

H5: CSR has direct and meaningful relation with patient's trust.

H6: CSR has direct and meaningful relation with patient's satisfaction.

H7: Customer company identification has direct and meaningful relation with patient's satisfaction

H8: Patient's trust has direct and meaningful relation with Customer company identification

H9: Patient's trust has direct and meaningful relation with satisfaction

\section{Methodology}

\subsection{Sampling and data collection}

A survey on customers of medical center in Iran is conducted to test hypotheses and the quantitative survey method and structured data collection was applied. The instrument of the survey was questionnaire composed from structured questions. Survey systems and paper questionnaires were used to reach respondents. A total of 550 survey instruments were distributed through a random sampling. Of the 505 returned questionnaires 52 were discarded due to high number of missing data, 405 were usable before analysis, variables were examined through various SPSS 18 procedures for accuracy of data entry, missing values, and fit between distributions and the assumptions of structural Equation modeling. Forty-eight cases were identified, through Mahalanobis distance analysis, as multivariate outliers with a Pvalue $<0.001$. These respondents were deleted, leaving 383 cases for 
analysis. The majority of respondent were female. 219 female (54.1\%) and 183 male (45.2 $\%) ; 20$ under the age of 20 (4.9\%), 80at the ages of 21-30 (19.8\%), 79 at the ages of $31-40(19.5 \%), 133$ at the ages of 41-50(32.8\%) and 93over the age of 50 (23\%). Most of the respondents, 213 (52.6) have bachelor's degree or higher degree as their latest degree, while 191(47.4\%) of the respondents also have under bachelor's degrees as their latest degree.87(21.5\%) of the respondents were under 6 month client of medical center,43(10,6\%)between 6-12 month, 49(12.1\%) 1-3 years, 52(12.8\%) between 3-5 years, $174(43 \%)$ over 5 years used the services of medical center.

\subsection{Data Analysis and Results}

In order to test the hypothesized relationships described above, scales measuring the constructs of the Conceptual model shown in Figure 1 are drawn and adapted from existing literature. All the scales are translated to Persian and then back-translated and the survey instrument is finalized. Before conducting the survey, a pilot test is done with sixty clients with the aim to purify the scales. CSR is measured by the six item developed by Perez and Bosque (2014) and Martinez Bosque (2013), In order to measure trust, the five items developed by Morgan and Haunt (1994) and Mayer et al (1995), customer company identification is measured by the six item developed by Martinez and Bosque (2013), Perez and Bosque (2014), for customer satisfaction is measured by Lai (2010), Hsu (2012), and finally loyalty is measured by five item developed by Parasuraman (2005), Perez and Bosque (2014), Slightly changed to fit and used in the present study. The items for each of these Constructs are measured by seven-point Likert scales (1=strongly disagree, $7=$ strongly agree). During the pretest procedure, respondents were encouraged to comment any question that they thought was unclear, ambiguous or that they were unable to answer. Some minor grammatical changes were made to the questionnaire following the pretest process. The items on the questionnaire were used because they met the criteria for the item analysis. Before testing the hypotheses via the structural model, we evaluate internal consistency, reliability, and convergent validity of the measures. AMOS 16.0 (maximum likelihood estimation) was employed to complete the analysis. As illustrated in Table 1, the Cronbach's alpha of each construct is between 0.851and 0.936, higher than the 0.7 recommended by Nunnally and Bernstein (1994), demonstrating adequate internal consistency. Composite reliability (CR) of all measures exceed 0.6 threshold suggested by Fornell and Larcker (1981), indicating a favorable level of internal consistency reliability. In addition, the average variance extracted (AVE) across the latent variables exceed the 0.5 benchmark recommended by Fornell and Larcker (1981)

Table 1: Result of Validity and Reliability

\begin{tabular}{|l|c|c|c|}
\hline Construct & AVE & CR & Cronbach Alpha \\
\hline Corporate social responsibility & 0.54 & 0.59 & 0.851 \\
\hline Trust & 0.74 & 0.69 & 0.893 \\
\hline Satisfaction & 0.59 & 0.61 & 0.930 \\
\hline Customer company identification & 0.61 & 0.7 & 0.904 \\
\hline Loyalty & 0.71 & 0.73 & 0.936 \\
\hline \multicolumn{3}{|c|}{} \\
\hline
\end{tabular}


In order to evaluate the multivariate normality Mardia's Test was conducted. If the ratio is less than 1.96 critical multivariate is considered normal [19]. The amount of critical proportion of for multivariate in this study was obtained 1.104 so normality was approved. to assess the adequacy and suitability of data for factor analysis of the two indicators. To evaluate the adequacy and appropriateness of the data for the two exploratory factor analysis, KMO index and Bartlett's test was used. The size of sampling adequacy (KMO) and Bartlett's test was significant. respectively in factor analysis by SPSS 0.973 (Index suitability for factor analysis and 0.000) as well as Bartlett's test results 9609.674 in a sig=0.000 and p value $<05 / 0$ sign the suitability of the data. There is a significant indication of the adequacy of the sample. For inferential statistics in this study, structural equation modeling in terms of measurement and structural models were estimated. First, the model should be examined fitting indicators as shows in table 2

Table 2: Structural model fit index (final revised model)

\begin{tabular}{|c|c|c|c|}
\hline Indexes & Drawn number & $\begin{array}{c}\text { The maximum } \\
\text { allowable }\end{array}$ & Result \\
\hline Chi-square / df & $\mathbf{9 9 8 . 9 9 / 3 1 8 = 3 . 1 2}$ & $\mathbf{5}<\mathbf{x}^{\mathbf{2}} / \mathbf{d f}<\mathbf{3}$ & Good fitness \\
\hline RMSEA & 0.07 & $0.08<<0.05$ & Good fitness \\
\hline CFI & 0.93 & 0.9 & Good fitness \\
\hline NFI & 0.92 & $>0.9$ & Good fitness \\
\hline NNFI $\longleftarrow$ TLI & 0.90 & $>0.9$ & Good fitness \\
\hline IFI & 0.93 & $>0.9$ & Good fitness \\
\hline RMR & 0.034 & $<0.05$ & Good fitness \\
\hline
\end{tabular}

According to the above table that all indices of fit, fitted confirmed the suitability of this location. The path to verify hypotheses were examined using AMOS software.

Standardize loadig factor has shown in figure 2 using AMOS software

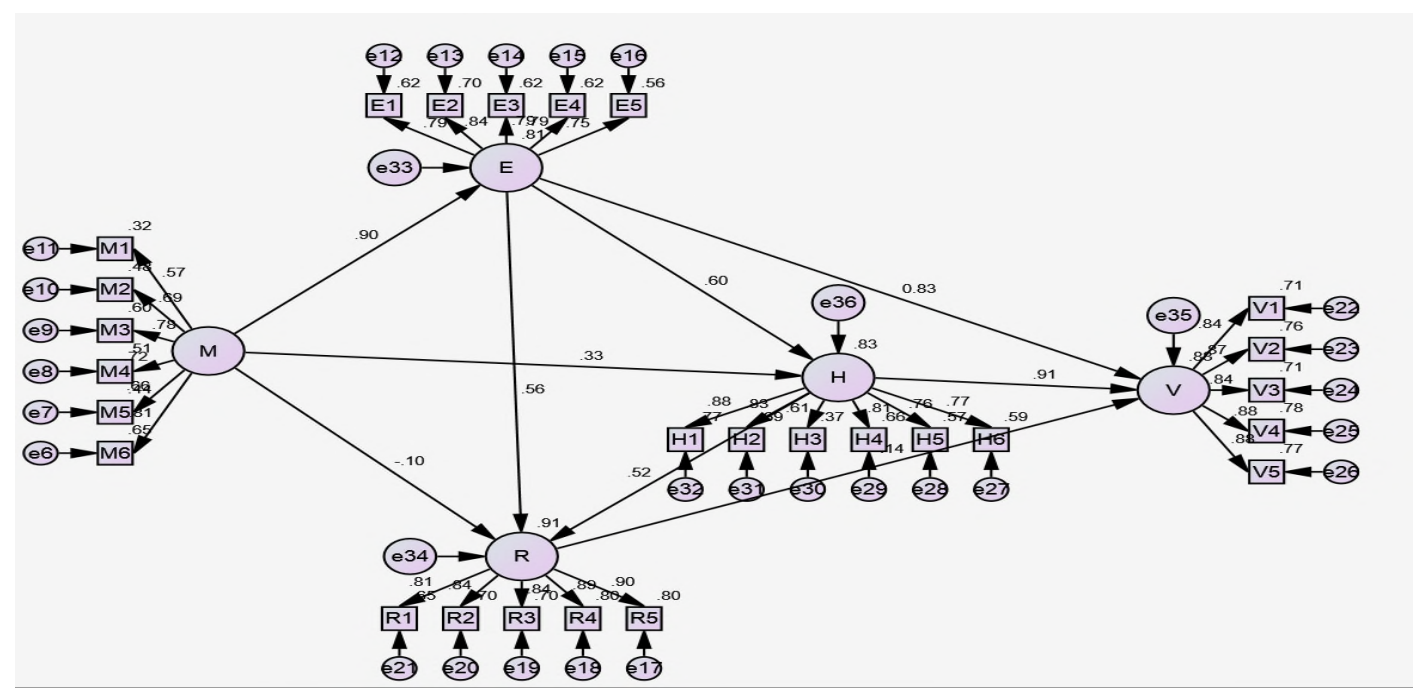

Figure 2: Customer loyalty model (Model standardized scores 
Table 3: summary of the hypothesized structural paths for models

\begin{tabular}{|l|c|c|c|}
\hline Structural paths & C.R & Factor loading & Result \\
\hline H1: Trust $\rightarrow$ Loyalty & 6.92 & 0.83 & Supported \\
\hline H2: : C-C identification $\rightarrow$ Loyalty & 7.66 & 0.9 & Supported \\
\hline H3: Satisfaction $\rightarrow$ Loyalty & 1.05 & 0.14 & Rejected \\
\hline H4: CSR $\rightarrow$ c-c identification & 3.33 & 0.33 & Supported \\
\hline H5: CSR $\rightarrow$ Trust & 12.96 & 0.9 & Supported \\
\hline H6: CSR $\rightarrow$ Satisfaction & -1.14 & -0.09 & Rejected \\
\hline H7: C-C identification $\rightarrow$ Satisfaction & 6.45 & 0.54 & Supported \\
\hline H8: Trust $\rightarrow:$ C-C identification & 5.88 & 0.6 & Supported \\
\hline H9: Trust $\rightarrow$ Satisfaction & 5.4 & 0.56 & Supported \\
\hline $\mathrm{X}^{2}=999.42 \quad \mathrm{df}=315$, p-value 0.0000, RMSEA $=0.07$ \\
\hline
\end{tabular}

According to the table above seven hypothesis were confirmed nevertheless two hypotheses rejected. Due to the lack of confirmation of 2 hypothesis in the medical center, in order to provide a new model by removing the two path were re-examined.

Table 4 shows the fitting indexes of the structural model in final state using AMOS software To confirm the validity of the structural model diagram of the final research model must first be investigated Fitting indexes of structural model. After it became clear that the final revised estimate model parameters fitted to this model is an estimate values for acceptable fit.

Figure 3: The final model (corrected) scores province. 
Bulletin de la Société Royale des Sciences de Liège, Vol. 85, 2016, p. 1026 - 1038

Table 4: structural model fit index (final revised model)

\begin{tabular}{|c|c|c|c|}
\hline Indexes & Drawn number & $\begin{array}{c}\text { The maximum } \\
\text { allowable }\end{array}$ & Result \\
\hline Chi-square / df & $998.99 / 318=3.14$ & $5<\mathrm{x}^{2} / \mathrm{df}<3$ & Good fitness \\
\hline RMSEA & 0.07 & $0.08<<0.05$ & Good fitness \\
\hline CFI & 0.93 & 0.9 & Good fitness \\
\hline NFI & 0.92 & $>0.9$ & Good fitness \\
\hline NNFI $\downarrow$ TLI & 0.89 & $>0.9$ & Good fitness \\
\hline IFI & 0.93 & $>0.9$ & Good fitness \\
\hline RMR & 0.034 & $<>0.05$ & Good fitness \\
\hline
\end{tabular}

Finally, the best model revised data, this model as the optimal model study, it is suggested. Figure 4. shows diagram of the final revised version. Also addition to the Direct effects, Indirect effects was evaluated by AMOS software the results shown in Table 5.

Table 5: overall effects, direct and indirect research structure in standard mode shows

\begin{tabular}{|c|c|c|c|c|}
\hline \multirow{4}{*}{$\begin{array}{c}\text { Independent variable } \\
\text { Dependent } \\
\text { variable }\end{array}$} & $\begin{array}{l}\text { Indirect } \\
\text { Effect }\end{array}$ & $\begin{array}{l}\text { Direct } \\
\text { Effect }\end{array}$ & $\begin{array}{l}\text { Total } \\
\text { Effect }\end{array}$ \\
\hline \multirow{3}{*}{$\begin{array}{c}\text { Corporate social } \\
\text { responsibility }\end{array}$} & Trust & - & 0.902 & 0.902 \\
\cline { 2 - 5 } & C-C identification & 0.543 & 0.328 & 0.871 \\
\cline { 2 - 5 } & Satisfaction & 0.952 & $-0 / 100$ & 0.852 \\
\cline { 2 - 5 } & Loyalty & 0.806 & - & 0.806 \\
\hline \multirow{2}{*}{ Trust } & C-C identification & - & 0.602 & 0.602 \\
\cline { 2 - 5 } & Satisfaction & 0.312 & 0.556 & 0.868 \\
\cline { 2 - 5 } & Loyalty & 0.667 & 0.83 & 1.49 \\
\hline \multirow{2}{*}{\begin{tabular}{c} 
C-C identification \\
\cline { 2 - 5 }
\end{tabular}} & Satisfaction & - & 0.517 & 0.517 \\
\hline \multirow{2}{*}{ Satisfaction } & Loyalty & 0.071 & 0.909 & 0.981 \\
\hline
\end{tabular}

\section{Discussion and conclusion}

this study adds additional empirical evidence to the recent observation.the positive effect of customer trust on customer loyalty was accepted in confirmation of (Johnson and Grayson; 2005; Keh and Xie; Van vurren et al; 2011) also trust indirectly had effect on loyalty via customer compa; 2009; ny identification. So, trust has both direct and indirect effect on loyalty. Positive and meaningful relation between customer company identification and loyalty confirmed as (Raman et al; 2014 and Kang et al; 2015. So Increasing customer identification with the medical center, increases patient's loyalty. Also the posive and direct effect of CSR on customer company identification as ( Marin et al; 2009; Lee; 2010; Perez\& Bosque; 2014) confirmed and also CSR had indirect effect on customer company identification via patient's trust. Due to the lack of investigations in the health sector, proving this hypothesis in the medical center is the first step for the promotion of literature in this field. The Positive and meaningful effect of CSR on customer trust (pivato, 2008; Hong and Rim, 2010; Homburg et al 2013; Ravdicin and Dezmida; 2014) and positive influence of trust on satisfaction as (Solayapan and Jayakrishnan ; 2010; Ndubisi ; 2012)were approved. Finally, it is important to note that 
the effect of CSR on customer satisfaction and patient's satisfaction on loyalty were not significant. These findings confirmed Kavaliauske and Stancikas (2014) research and surprisingly contradict results from (Luo and Bhattacharya, 2006; He and $\mathrm{Li}, 2011$ ), who established a positive influence of CSR on consumer satisfaction with the company and and confirmed (Ali,2014; Jung et al; 2015) and contradict results from (Alden et al,2004; Kim et al 2008; Arikan and Guner; 2013; Hasebur et al) who find positive relationship between customer satisfaction and customer loyalty. The other result was confirmation of indirect effect of CSR on patients' satisfaction via trust, emphasizes as a result of the role of trust in creation of patients' satisfaction in medical centers. However, these authors argue that the role of CSR on satisfying customers is not likely one that lasts. Other findings were the confirmation of positive and direct meaningful effect of patient' trust on Customer company identification as (Keh and Xie; 2009; He et al; 2012) and also positive effect of patient' trust on patient's satisfaction as (Solayapan\& Jayakrishnan; 2010; Ndubisi; 2012). Accordingly, the effect of social responsibility on loyalty was approved indirectly having considered the mediating role of customer trust, customer company identification, and patient satisfaction. This study examines the effect that CSR have on customer related outcomes such as customer company identification, customer satisfaction and trust and also investigate the effect of customer company identification, customer satisfaction and trust on loyalty and finally offering loyalty model for healthcare centers. Theoretically, this study makes a number of contributions to literature. It test and confirm CSR plays important role to achieving trust and customer company identification . Thus, this study expands the traditional view concerning CSR's effect on customers and suggest that CSR create more trust and hence, more loyal customer and suggests that CSR associations do not only affect product evaluation, but also increase customer trust. . Customers are more likely to believe that responsible companies operate honestly in their activities and reflect interests of both parties in the relationship when making decisions. Moreover, customers are more willing to relate and identify with the medical centers witch carrying out socially responsible initiatives. The results also support that customer trust is the most important attribute in the context of services. In the other word it is trust of customers that lead to loyalty, but CSR's role as an attribute is not only important but also determinant. When need is aroused to get treatment. Loyal patients in the same hospital visits are reset again. Thus, Health care centers are able to achieve competitive advantage and profitability by enhancing features that make patients loyal [4]. The findings will be an important managerial implications for medical centers to create and build strong and longlasting relationships with customers:

So following recommended is suggested to medical centers managers :

- By creating a culture of customer privacy and prevent the disclosure of information related to patient treatment increased the confidence of patients.

- In order to earn the trust and loyalty of patients, is recommended that a service beyond emotional connections with their patients through ethical business operation

- By creating a culture of competence, benevolence and integrity in your field staff to build trust between doctors and patients, and subsequently prepare loyalty 
- Due to perceived social responsibility activities create perception of sustainable, distinctive and basic attributes of organization for the client and thereby enhances sense of identification with the medical center

- Develop customer relationship management strategies and developing relationships with all stakeholders.

- A system to handle customer complaints, active and prominent in their own medical center.

The limits can be stated fieldwork. Given that the study population comprised patients and the mood is not good and often were anxious and they need different motivational factors to respond appropriately. The process of collecting the views of this group was very trouble.

\section{References}

1. Chung, K, Yu, J., Choi, M. \& Shin, J. The Effects of CSR on Customer Satisfaction and Loyalty in China: The Moderating Role of Corporate Image, Journal of Economics, Business and Management 2015; Vol. 3, No. 5:542-547.

2. Chen, Shu-Ching. Customer value and customer loyalty: Is competition a missing link? Journal of Retailing and Consumer Services 2015; Vol. 22: 107-116.

3. Maleki , S. , (1391 ), Effect of Corporate Social Responsibility on customer loyalty : Sepah Bank , International Marketing Conference, October 1391; pp. 21-1.

4. Kumar, P.N., Jacob, A., Thota, S. Impact of healthcare marketing and branding on hospital services, International Journal of Research Foundation of Hospital \& Healthcare Administration 2014; 2(1):1924.

5. Fatemifar, Azade. The effect of corporate social responsibility on customer loyalty through customer company identification, trust and customer loyalty (case study: Shahid Shoorideh Medical center, 2015, [M.A thesis]. Tehran: Payame Noor University of Management and Accounting; 2015.

6. Perez, A., and Bosque, I.R.D.,(2014),An integrative framework to understand How CSR affect customer loyalty through Identification, Emotions and Satisfaction, Journal of Business Ethics, DOI 10.1007/s10551-2177-9.

7. Martinez, p., Bosque, R.D. CSR and loyalty: The role of trust, customer identification with company and satisfaction, International Journal of Hospitality Management 2013; vol.35: 89- 99

8. Amini, M.T., Salar, J: Strategic thinking and vision. Tehran: payame Noor University. 2014.

9. Takahashi, T., Ellen, M., \& Brown, A. Corporate social responsibility and hospitals: US theory, Japanese experiences, and lessons for other countries, Healthcare Management Forum. Gestion des soins de sante, Winter/Hiver, (2013); 176-179.

10. Purwanto, Yadi. The Effect of Service Delivery Performance and Corporate Social Responsibility on Institutional Image and Competitive Advantage and its Implication on Customer Trust (A Survey of Private Hospitals in Solo Raya), Issues in Social and Environmental Accounting. 2010, 2, 168-185.

11. Arikan, E \& Guner, S .The impact of corporate social responsibility, service quality and customer company identification on customers, Journal of Social and Behavioral Sciences2013; 99: $304-313$.

12. Kang, Jun, Aljandro. T .B, Groza. M. D. Customer company identification and the effectiveness of loyalty programs, Journal of Business Research 2015; 18(2), 464-471.

13. Sollner, M., Leimeister, J. M. What we really know about antecedents of trust: A critical review of the empirical information systems literature on trust, Journal of psychology of trust, chapter, 2013; 7: 127-140. 
14. Barnes, Aimie-Jade. Corporate Social Responsibility and its effects on Brand Trust, Masters of Business thesis, Auckland University of Technology, 2011; pp.7-35.

15. Homburg, c., Stierl, M. \& Bornemann.T. Corporate social Responsibility in Business-To- Business markets: How organizational customers account for supplier corporate social responsibility engagement, Journal of Marketing 2013; vol.77: 54-72.

16. Shahroudi, K., Taghizadeh. J., Roydel, H. Social role of banks as a determinant of consumer behavior (Case Study: Bank, Rasht ), IRIB International Conference1391;

17. Bagozzi, B. and Yi, Y. "On the Evaluation of Structural Equation Models", Journal of the Academy of Marketing Science1988; 16(1): 74-94.

18. Azar .A, Khadivar, A: The use of multivariate statistical analysis management. Tehran: Negahe danesh.

19. Mardia, K.V., Mardia's test of Multinormality, Encyclopedia of Statistical sciences, 1985, vol. 5: 227221.

20. Van vuuren,T., Robert-Lombard, M \&Van Tonder, ECustomer satisfaction, trust and commitment as predictors of customer loyalty within an optometric practice environment, Journal of southern African Business Review, 2012, volume.16,Number 3, pp.81-96.

21.

aman, M., Lim.W, Nair.S, The impact of corporate social responsibility on consumer loyalty, Journal of Kajan Malaysia, 2012 .vol.30, No.2, pp.71-93.

22. Radvieciene, I., Dzemyda, I., The influence of customer perceived ethicality on customer loyalty and trust, $8^{\text {th }}$ International conference business and management, May 2014, pp.154163.

23. Purwanto, Yadi. The Effect of Service Delivery Performance and Corporate Social Responsibility on Institutional Image and Competitive Advantage and its Implication on Customer Trust (A Survey of Private Hospitals in Solo Raya), Issues in Social and Environmental Accounting,2010;2, 168-185.

24. Pivato, S., Misani, N., Tencati, A., 2008. The impact of corporate social responsibility on consumer trust: the case of organic food. Business Ethics: A European Review17, 3-12.

25. Ndubisi, N. Mindfulness, reliability, pre-emptive conflict handling, customer orientation and outcomes in Malaysia's healthcare sector, Journal of Business Research,2012; vol. 6, pp. 537-546.

26. Lii, Y. S. and Lee, M. "Doing Right Leads to Doing Well: When the Type of CSR and Reputation Interact to Affect Consumer Evaluations of the Firm." Journal of business ethics; 2010; pp. 1-13

27. Kim, K.H., Kim, K.S., Kim, D.Y., Kim, J.H. \& Kang , S.H. , “ Brand equity in hospital marketing ”, Journal of Business Research; 2008; Vol. 61, PP. 75-82.

28. Keh. H. T. \& Xie, Y., (2009), Corporate reputation and customer behavioral intention: The role of trust, identification and commitment, Industrial Marketing Management, 38,732-742.

29. Kang, Jun, Aljandro.T.B, Groza.M.D: customer company identification and the effectiveness of loyalty programs, Journal of Business Research, 2015; Vol. 18, Issiue. 2, 464-471.

30. Johnson ,D, \& Grayson, K," Cognitive and affective trust in service relationships”, Journal of Business Research; 2005; 58, 500- 507.

31. Jang, Y. J. Kim, W.G., Lee ,H. Y. Coffee shop consumers' emotional attachment and loyalty to green stores: The moderating role of green consciousness, International Journal of Hospitality Management ,2015; Vol. 44 ,146-156. 
32. Hsiu-Fen L. (2011). An empirical investigation of mobile banking adoption: The effect of innovation attributes and knowledge-based trust. International Journal of Information Management; 31: 252-260.

33. Hong, S. Y., and Rim, H., The influence of customer use of corporate websites: corporate social responsibility, trust, and word-of-mouth communication, Public Relations Review; 2010, Vol. 36, pp. 389-391.

34. Homburg, c., Stierl, M. \& Bornemann.T., corporate social Responsibility in Business-ToBusiness markets: How organizational customers account for supplier corporate social responsibility engagement, Journal of Marketing, 2013; vol.77, p.54-72.

35. He, H., Li, Y., Harris, L., Social identity perspective on brand loyalty, Journal of Business Research, 2012; V01. 65, pp. 648-657.

36. Brown, T., \& Dacin, P. The Company and the Product: Corporate Associations and Consumer Product Responses. Journal of Marketing, 1997; 61(1), 68-84.

37. Alden, D.L., Hao, D. M., Bhawuk, D. Client satisfaction with reproductive health-care quality: integrating business approaches to modeling and measurement, Journal of social science and medicine, 2004; vol.59, pp.2219-2232.

38. Hasebur, Rahman, Md. "Corporate social responsibility for brand image and customer satisfaction: Assessment of Grameen phone user's in Bangladesh, International Journal of Research Studies in Management, 2014; Vol.3, No.1, pp.41-49. 